\title{
The Marriage of Protein and Lanthanide: Unveiling A Novel Time- Resolved Fluorescence Sensor Array Regulated by pH Toward High- Throughput Assay of Metal Ions in Biofluids
}

Zi-Yang Lin ${ }^{1}$, Zhi-bei Qu², Zi-Han Chen ${ }^{1}$, Xin-Yue Han ${ }^{1}$, Ling-Xue Deng ${ }^{1}$, Qingying Luo ${ }^{3}$, Zongwen $\operatorname{Jin}^{3}$, Guoyue Shi ${ }^{1}$, Min Zhang ${ }^{1 *}$

${ }^{1}$ School of Chemistry and Molecular Engineering, Shanghai Key Laboratory for Urban Ecological Processes and EcoRestoration, East China Normal University, 500 Dongchuan Road, Shanghai 200241, China. Email: mzhang@,chem.ecnu.edu.cn

\footnotetext{
${ }^{2}$ Joint Research Center for Precision Medicine, School of Chemistry and Chemical Engineering and School of Medicine, Sixth People's Hospital South Campus, Shanghai Jiao tong University, Shanghai 200240, China.

${ }^{3}$ Research Center for Micro/Nano System \& Bionic Medicine, Institute of Biomedical \& Health Engineering, Shenzhen Institutes of Advanced Technology, Chinese Academy of Sciences, 1068 Xueyuan Avenue, Shenzhen, 518055, China.
}

\section{Contents}

Figure S1. Structure of original BSA (pdb ID: 4f5s).

Figure S2. Excitation and emission spectra of BSA and Trp.

Figure S3. Absorption spectrum of BSA.

Figure S4. An illustration of the antenna effect.

Figure S5. Fluorescence lifetime data with corresponding fitting curves.

Figure S6. Scheme illustration of the TRF detection mode used in our work.

Figure S7. Circular dichroism (CD) spectra of $\mathrm{BSA} / \mathrm{Tb}^{3+}$ in Tris- $\mathrm{HCl}$ with two $\mathrm{pHs}(\mathrm{pH}=7.4$ and 8.5).

Figure S8. Fluorescence responses of $\mathrm{Tb}^{3+}$ in the presence of various concentrations of BSA in Tris-HCl buffer ( $\mathrm{pH}=7.4)$.

Figure S9. The optimization of reaction time between $\mathrm{Tb}^{3+}$ and BSA in Tris- $\mathrm{HCl}$ buffer $(\mathrm{pH}=7.4)$.

Figure S10. The optimization of reaction time between $\mathrm{BSA} / \mathrm{Tb}^{3+}$ and $\mathrm{Cu}^{2+}$ in Tris- $\mathrm{HCl}$ buffer $(\mathrm{pH}=7.4)$.

Figure S11-S12. The patterns of the 17 metal ions based on the TRF changes $\left(\mathrm{F}_{0}-\mathrm{F}\right) / \mathrm{F}_{0}$; Each at $10 \mu \mathrm{M}$ and

$1 \mu \mathrm{M}$, respectively.

Figure S13. Circular dichroism (CD) spectra of BSA, BSA/metal ions, BSA $/ \mathrm{Tb}^{3+}, \mathrm{BSA} / \mathrm{Tb}^{3+} / \mathrm{metal}$ ions in Tris-HCl buffer ( $\mathrm{pH}=7.4)$.

Figure S14. Absorption spectra of $\mathrm{BSA} / \mathrm{Tb}^{3+}$ and $\mathrm{BSA} / \mathrm{Tb}^{3+}$ respectively challenged with different metal ions.

Figure S15. Fluresecence or TRF spectra of BSA, BSA/ $\mathrm{Tb}^{3+}$, and $\mathrm{BSA} / \mathrm{Tb}^{3+}$ respectively challenged with different metal ions. 
Figure S16. Illustration of the BSA protein and the combined $\mathrm{Tb}^{3+}$ in the presence of sodium ions from the CG-MD simulations.

Figure S17-19. Heat map derived from the TRF response patterns of $\mathrm{BSA} / \mathrm{Tb}^{3+}$ sensors against $\mathrm{Cu}^{2+}, \mathrm{Co}^{2+}$, and $\mathrm{Fe}^{3+}$.

Figure S20-S21. TRF response patterns of BSA $/ \mathrm{Tb}^{3+}$ sensors against the mixture of $\mathrm{Fe}^{2+} / \mathrm{Fe}^{3+}$ and $\mathrm{Cr}^{3+} / \mathrm{Cr}^{6+}$.

Figure S22. PCA plots for the TRF patterns of BSA/ $\mathrm{Tb}^{3+}$ sensors toward the mixtures of $\mathrm{Cu}^{2+} / \mathrm{Fe}^{3+}$ in artificial saliva.

Table S1. Detection of $\mathrm{Fe}^{3+}$ in Sweat using BSA $/ \mathrm{Tb}^{3+}$ sensor array.

Table S2-3. Comparison about sensitivity between this work and other fluorescent sensors.

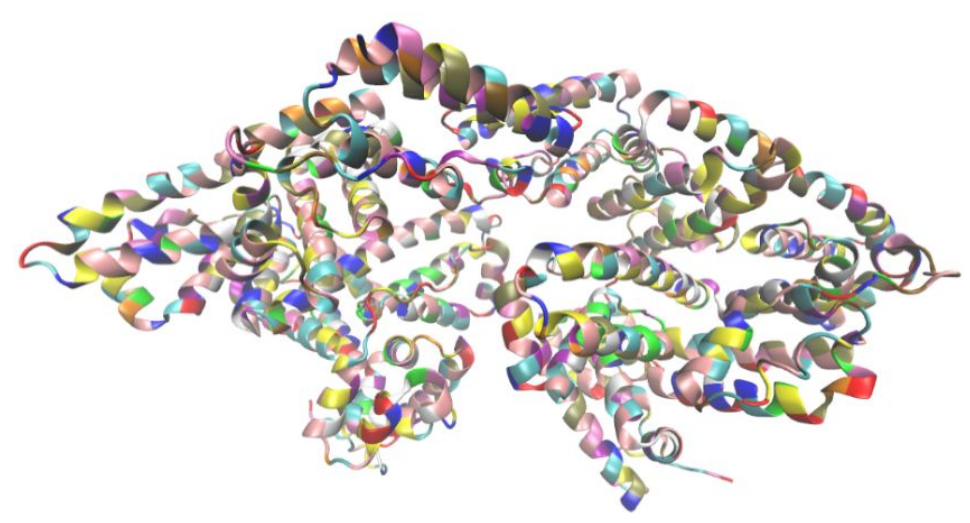

Figure S1. Structure of original BSA (pdb ID: 4f5s).



b

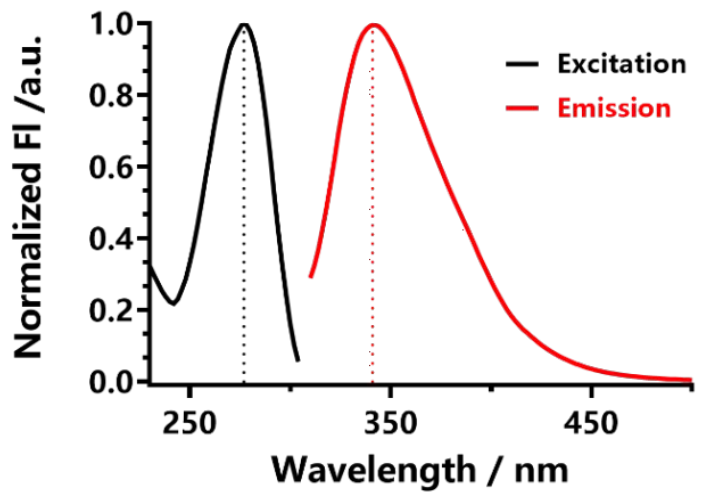

Figure S2. Excitation and emission spectra of (a) BSA and (b) Trp by using traditional measurements (without a delay time and a gate time of 20 us used). 


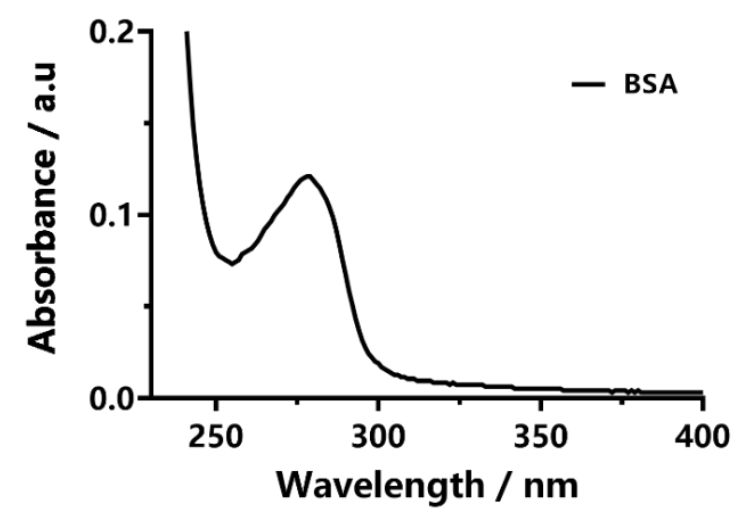

Figure S3. Absorption spectrum of BSA.



Fluorescence

Figure S4. An illustration of the antenna effect, wherein incident excitation $(\sim 280 \mathrm{~nm})$ is first absorbed by BSA and then transferred to $\mathrm{Tb}^{3+}$.
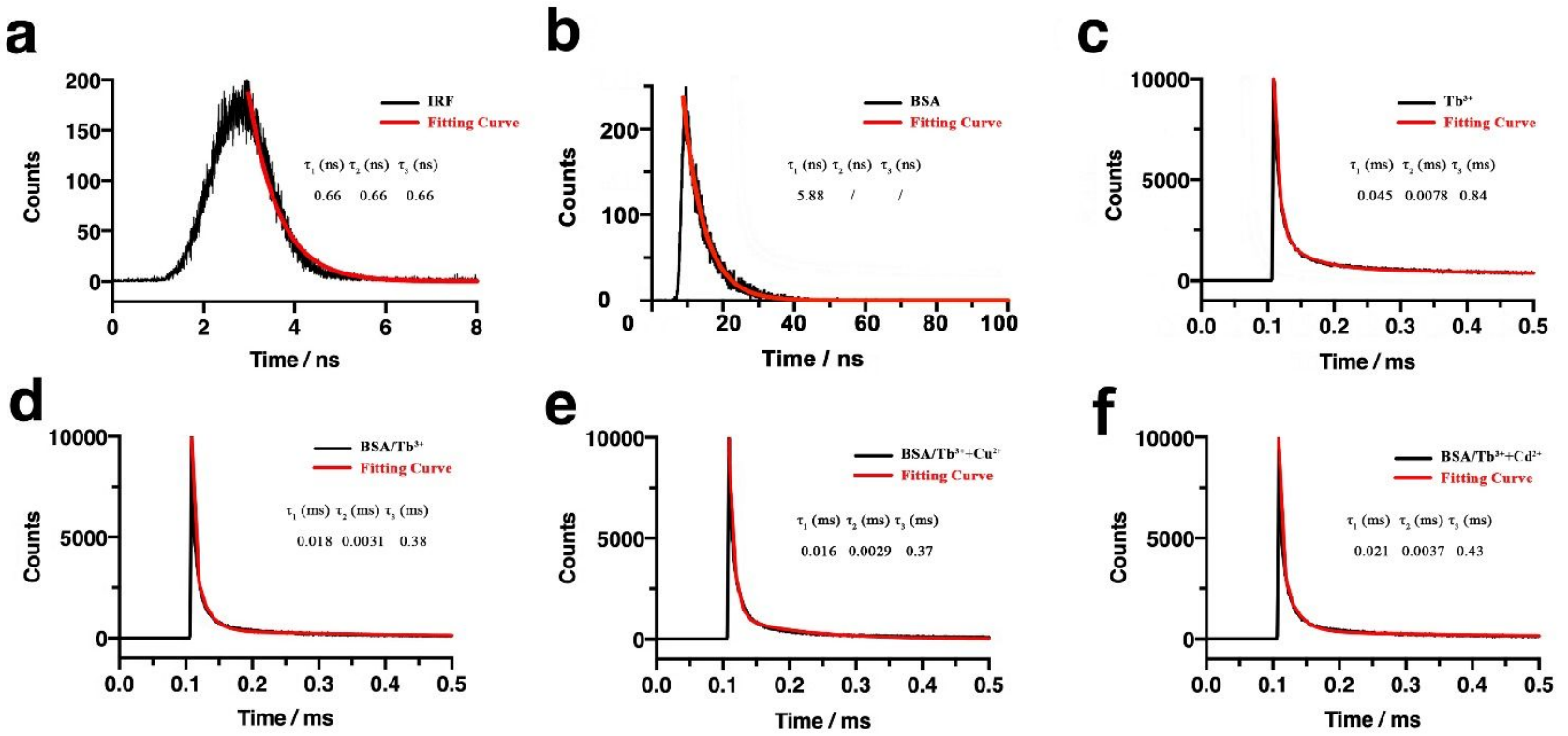

Figure S5. Fluorescence lifetime data with its corresponding fitting curves. (a) Instrucment response function; (b) BSA; (c) $\mathrm{Tb}^{3+}$; (d) BSA/ $\mathrm{Tb}^{3+}$; (e) BSA/ $\mathrm{Tb}^{3+}+\mathrm{Cu}^{2+}$; (f) BSA/ $\mathrm{Tb}^{3+}+\mathrm{Cd}^{2+}$. Note: We have analyzed the average fluorescence lifetime as well as each lifetime component $(\tau)$. Moreover, the IRF (instrument response function) that was used to deconvolute the lifetime was also plotted, and the 
corresponding equation was $\mathrm{y}=0.081+46.21 \mathrm{e}(-(-\mathrm{x}-2.98) / 0.66)+$ $73.82 e(-(x-2.98) / 0.66)+68.65 e(-(x-2.98) / 0.66)$. Compared with the long fluorescence lifetime of lanthanide complexes, the average fluorescence lifetime of IRF was so short that can be neglected (0.66 ns).

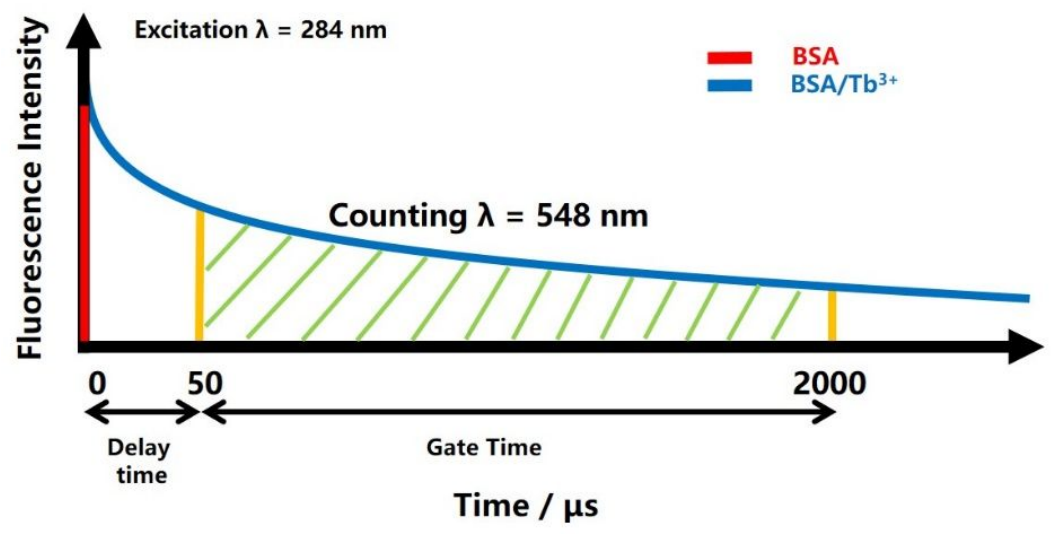

Figure S6. Scheme illustration of the TRF detection mode used in our work, in which a delay time of $50 \mu$ s and a gate time of $2000 \mu$ s were used.

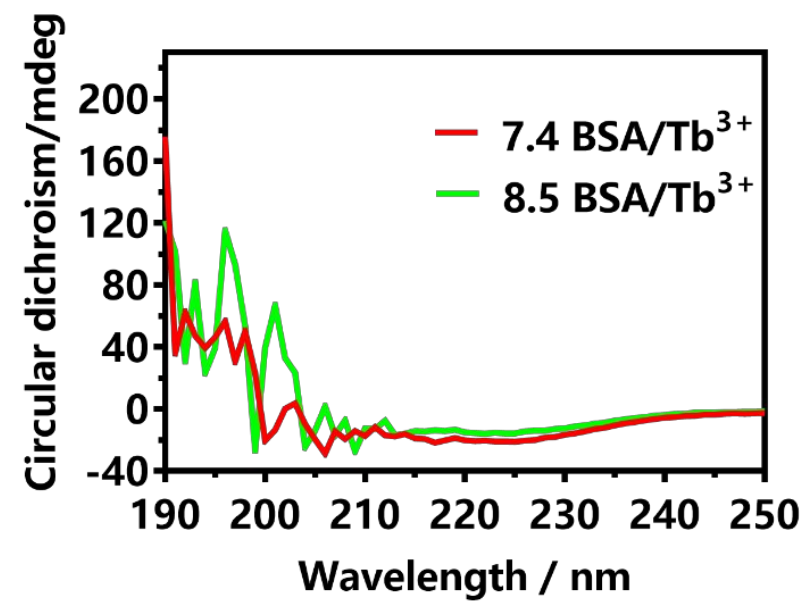

Figure S7. Circular dichroism (CD) spectra of $\mathrm{BSA} / \mathrm{Tb}^{3+}$ in Tris- $\mathrm{HCl}$ with two $\mathrm{pHs}(\mathrm{pH}=7.4$ and 8.5). 


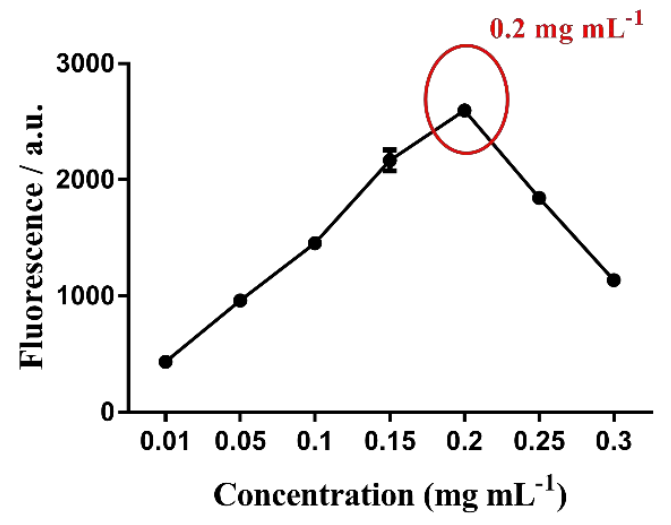

Figure S8. TRF responses of $\mathrm{Tb}^{3+}$ in the presence of various concentrations of BSA in Tris-HCl buffer ( $\mathrm{pH}=7.4)$.

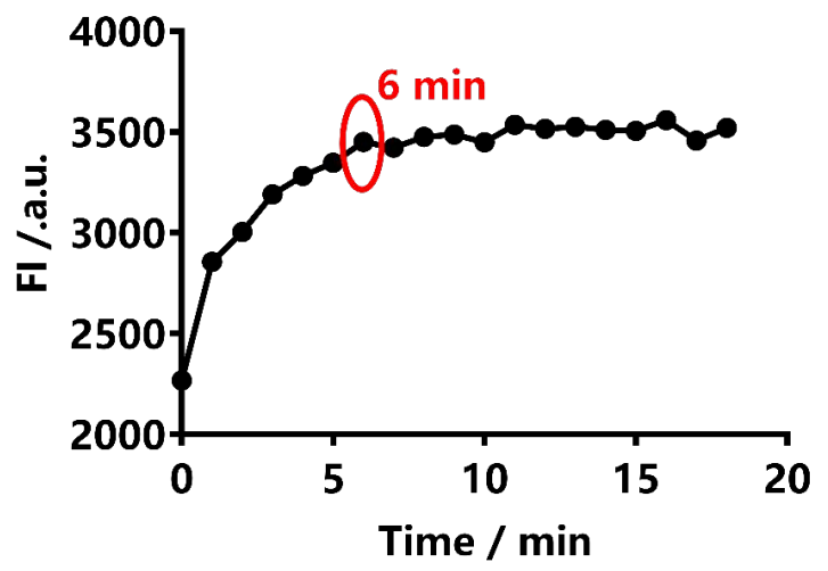

Figure S9. The optimization of reaction time between $\mathrm{Tb}^{3+}$ and $\mathrm{BSA}$ in Tris- $\mathrm{HCl}$ buffer $(\mathrm{pH}=7.4)$.

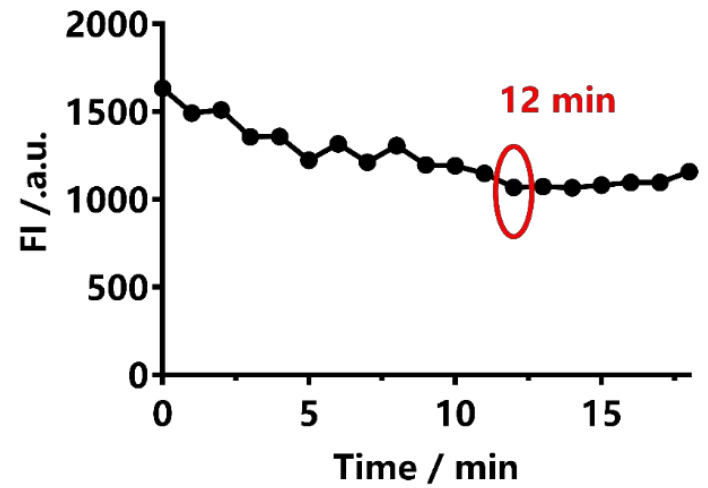

Figure S10. The optimization of reaction time between $\mathrm{BSA} / \mathrm{Tb}^{3+}$ and $\mathrm{Cu}^{2+}$ in $\mathrm{Tris}-\mathrm{HCl}$ buffer ( $\mathrm{pH}=7.4)$. 
b

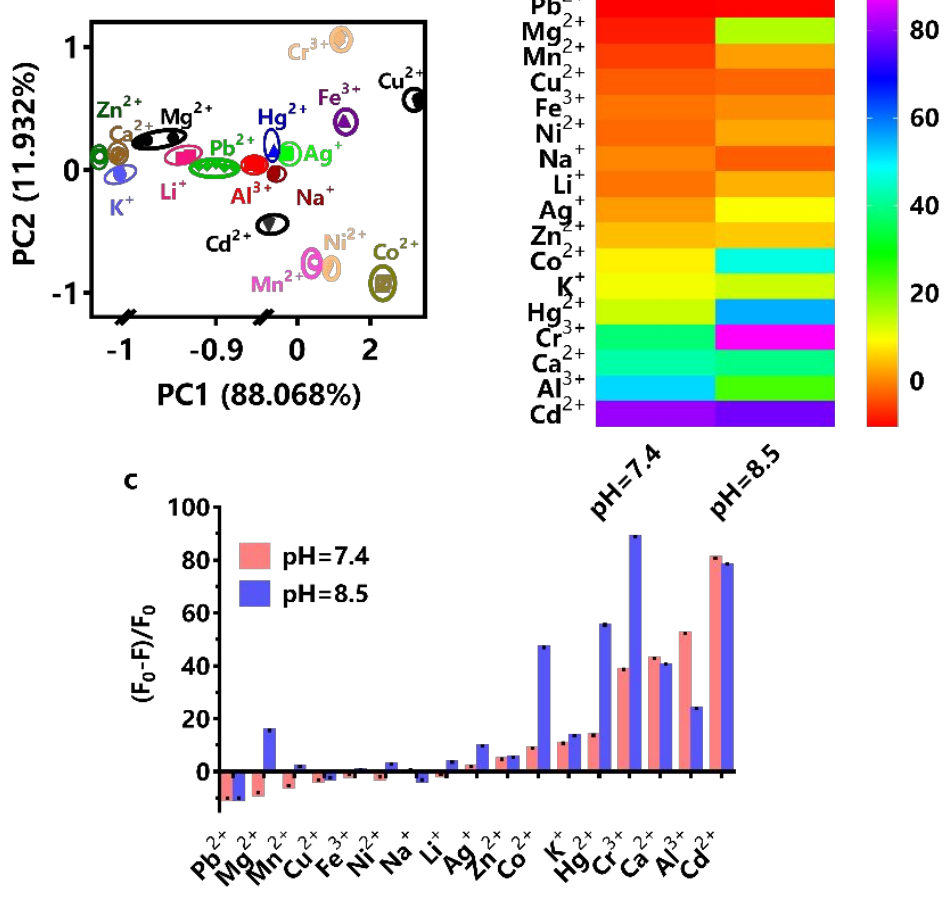

Figure S11. (a) The patterns of the 17 metal ions based on the TRF changes $\left(\mathrm{F}_{0}-\mathrm{F}\right) / \mathrm{F}_{0}$; (b) Heat map based on the TRF patterns of $\mathrm{BSA} / \mathrm{Tb}^{3+}$ sensor array; (c) PCA plot for the discrimination of 17 metal ions. Each at $10 \mu \mathrm{M}$.
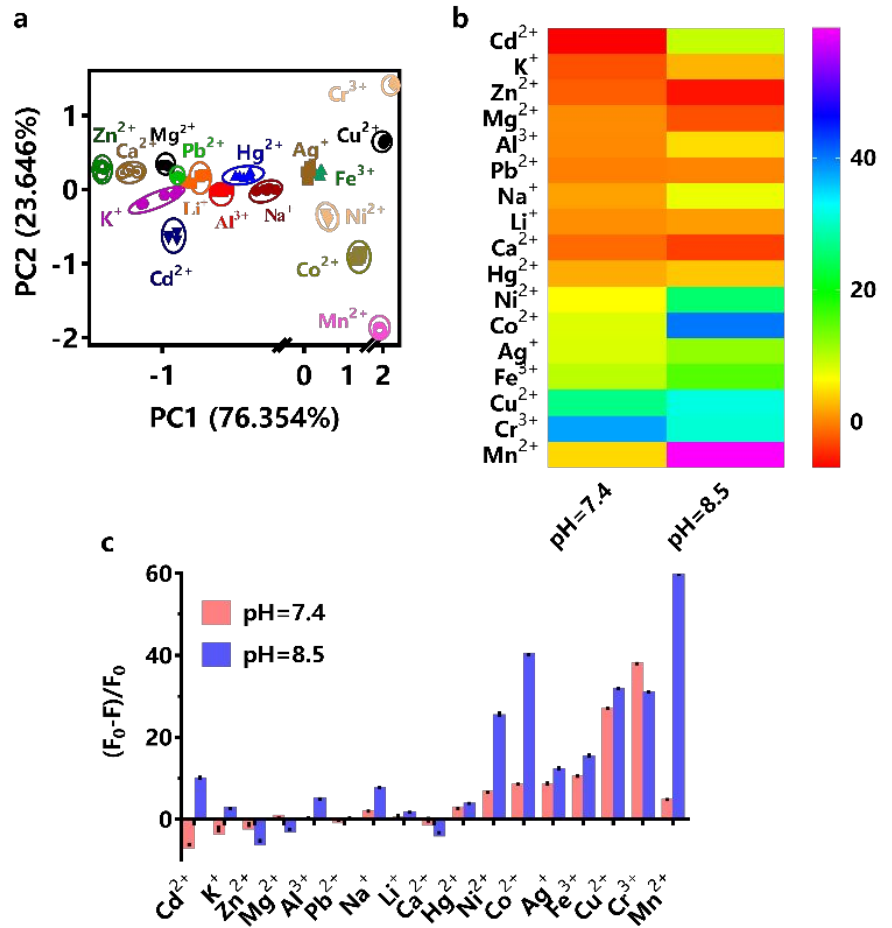

Figure S12. (a) The patterns of the 17 metal ions based on the TRF changes $\left(\mathrm{F}_{0}-\mathrm{F}\right) / \mathrm{F}_{0}$; (b) Heat map based on the TRF patterns of BSA/Tb ${ }^{3+}$ sensor array; (c) PCA plot for the discrimination of 17 metal ions. Each at $1 \mu \mathrm{M}$. 

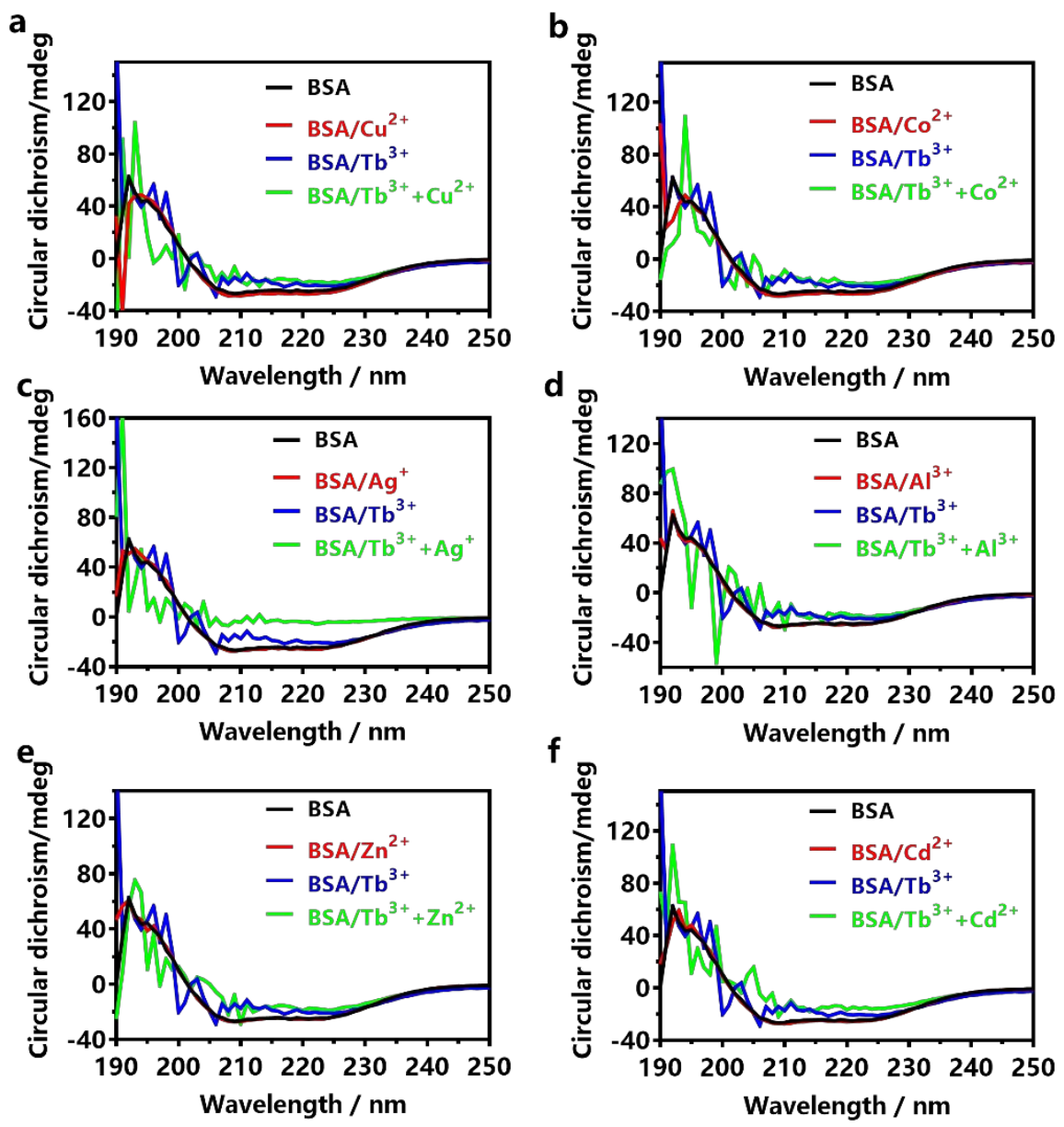

Figure S13. (a) Circular dichroism (CD) spectra of $\mathrm{BSA}, \mathrm{BSA} / \mathrm{Cu}^{2+}, \mathrm{BSA} / \mathrm{Tb}^{3+}, \mathrm{BSA} / \mathrm{Tb}^{3+}+\mathrm{Cu}^{2+}$; (b) $\mathrm{BSA}, \mathrm{BSA} / \mathrm{Co}^{2+}, \mathrm{BSA} / \mathrm{Tb}^{3+}, \mathrm{BSA} / \mathrm{Tb}^{3+}+\mathrm{Co}^{2+}$; (c) $\mathrm{BSA}, \mathrm{BSA} / \mathrm{Ag}^{+}, \mathrm{BSA} / \mathrm{Tb}^{3+}, \mathrm{BSA} / \mathrm{Tb}^{3+}+\mathrm{Ag}^{+}$; (d) $\mathrm{BSA}, \mathrm{BSA} / \mathrm{Al}^{3+}, \mathrm{BSA} / \mathrm{Tb}^{3+}, \mathrm{BSA} / \mathrm{Tb}^{3+}+\mathrm{Al}^{3+}$; (e) $\mathrm{BSA}, \mathrm{BSA} / \mathrm{Zn}^{2+}, \mathrm{BSA} / \mathrm{Tb}^{3+}, \mathrm{BSA} / \mathrm{Tb}^{3+}+\mathrm{Zn}^{2+}$; (f) $\mathrm{BSA}, \mathrm{BSA} / \mathrm{Cd}^{2+}, \mathrm{BSA} / \mathrm{Tb}^{3+}, \mathrm{BSA} / \mathrm{Tb}^{3+}+\mathrm{Cd}^{2+}$ in Tris-HCl buffer $(\mathrm{pH}=7.4)$.

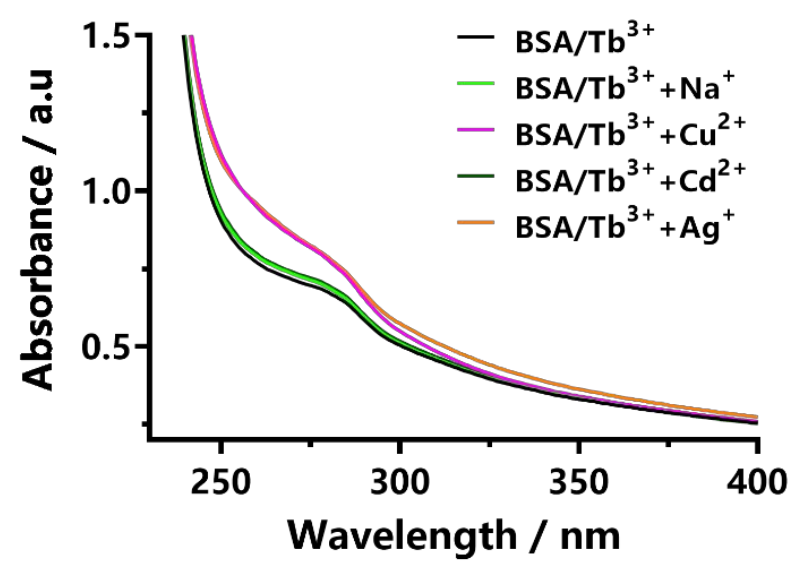

Figure S14. Absorption spectra of $\mathrm{BSA} / \mathrm{Tb}^{3+}$ and $\mathrm{BSA} / \mathrm{Tb}^{3+}$ respectively challenged with different metal ions $\left(\mathrm{Na}^{+}, \mathrm{Cu}^{2+}, \mathrm{Cd}^{2+}\right.$ or $\left.\mathrm{Ag}^{+}\right)$. 
a
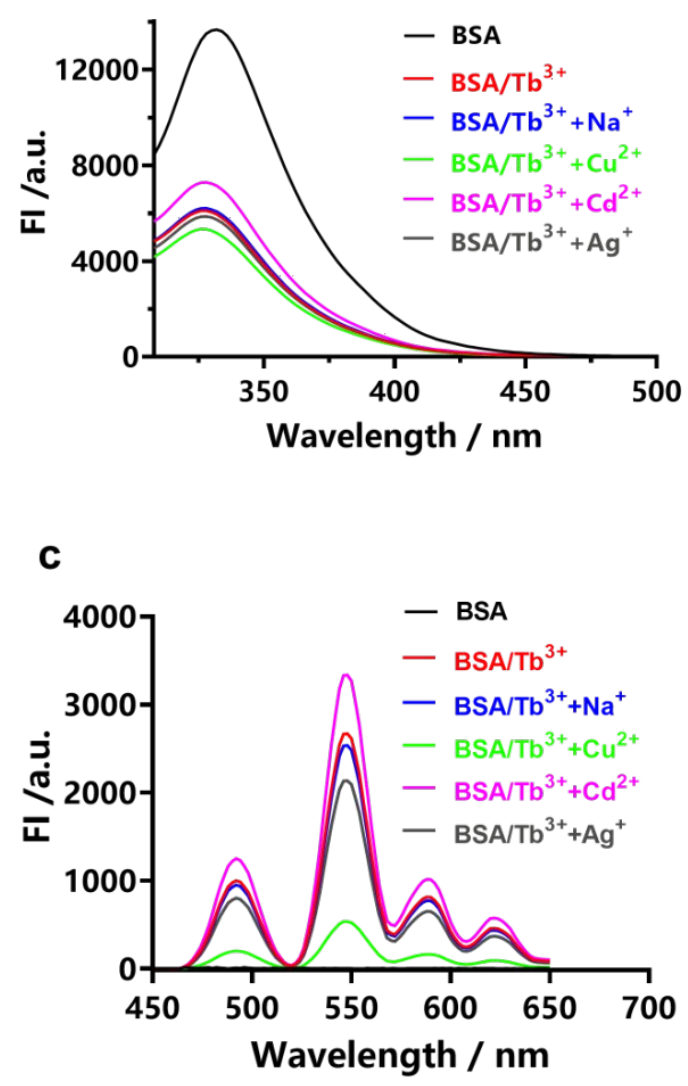

b

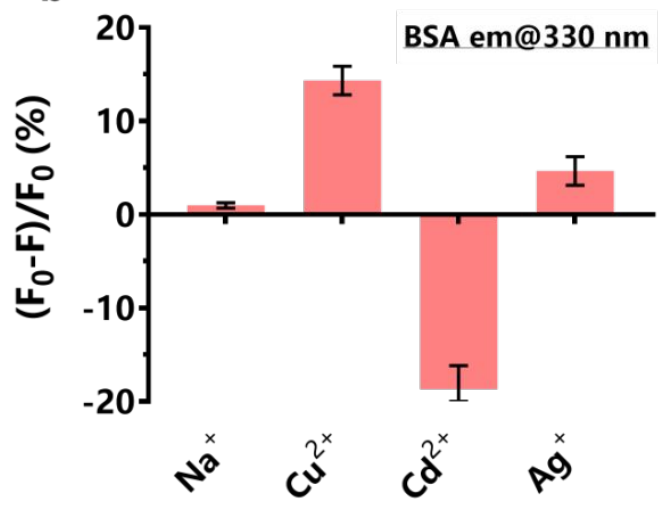

d

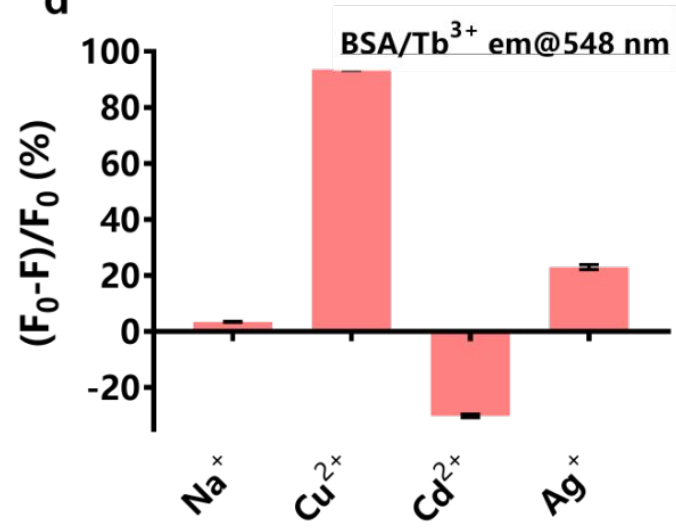

Figure S15. (a) Fluresecence spectra of $\mathrm{BSA}, \mathrm{BSA} / \mathrm{Tb}^{3+}$, and $\mathrm{BSA} / \mathrm{Tb}^{3+}$ respectively challenged with different metal ions (including $\mathrm{Na}^{+}, \mathrm{Cu}^{2+}, \mathrm{Cd}^{2+}$ or $\mathrm{Ag}^{+}$) measured by traditional detection mode (without a delay time and a gate time of $20 \mu \mathrm{s}$ used). (b) Fluorescence intensities at $300 \mathrm{~nm}$ of BSA $/ \mathrm{Tb}^{3+}$ respectively challenged with different metal ions (including $\mathrm{Na}^{+}$, $\mathrm{Cu}^{2+}, \mathrm{Cd}^{2+}$ or $\mathrm{Ag}^{+}$) measured by traditional detection mode (without a delay time and a gate time of 20 us used). (c) TRF spectra of BSA, BSA/Tb ${ }^{3+}$, and $\mathrm{BSA} / \mathrm{Tb}^{3+}$ respectively challenged with different metal ions (including $\mathrm{Na}^{+}, \mathrm{Cu}^{2+}, \mathrm{Cd}^{2+}$ or $\mathrm{Ag}^{+}$) measured by TRF detection mode (a delay time of $50 \mu \mathrm{s}$ and a gate time of 2000 us used). (d) TRF intensities at $548 \mathrm{~nm}$ of BSA $/ \mathrm{Tb}^{3+}$ respectively challenged with different metal ions (including $\mathrm{Na}^{+}$, $\mathrm{Cu}^{2+}, \mathrm{Cd}^{2+}$ or $\mathrm{Ag}^{+}$) measured by TRF detection mode (a delay time of 50 us and a gate time of 2000 us used).

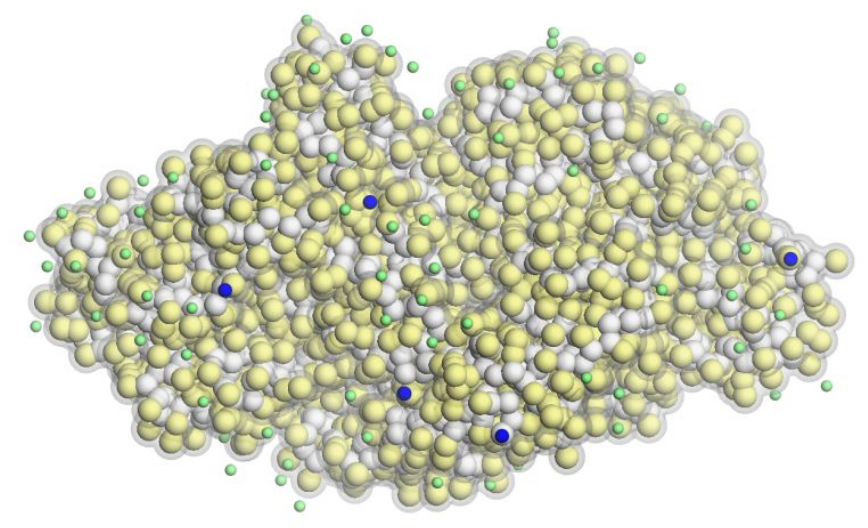


Figure S16. Illustration of the BSA protein and the combined $\mathrm{Tb}^{3+}$ in the presence of $\mathrm{Na}^{+}$from the CG-MD simulations. Yellow and white balls represent BSA residue and backbone particles. Green balls represent combined $\mathrm{Tb}^{3+}$ while blue balls stand for absorbed $\mathrm{Na}^{+}$. Waters, non-combined ions and countered $\mathrm{Cl}^{-}$were invisible to make the image clear.

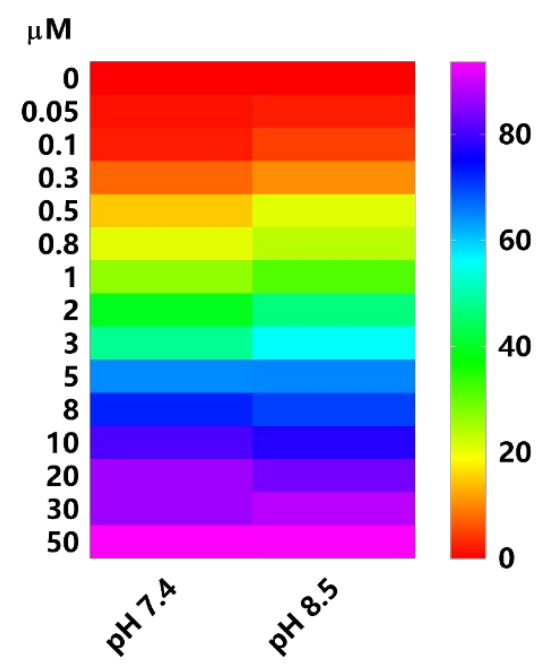

Figure S17. Heat map derived from the TRF response patterns of $\mathrm{BSA} / \mathrm{Tb}^{3+}$ sensors against $\mathrm{Cu}^{2+}$.



Figure S18. Heat map derived from the TRF response patterns of $\mathrm{BSA} / \mathrm{Tb}^{3+}$ sensors against $\mathrm{Co}^{2+}$. 


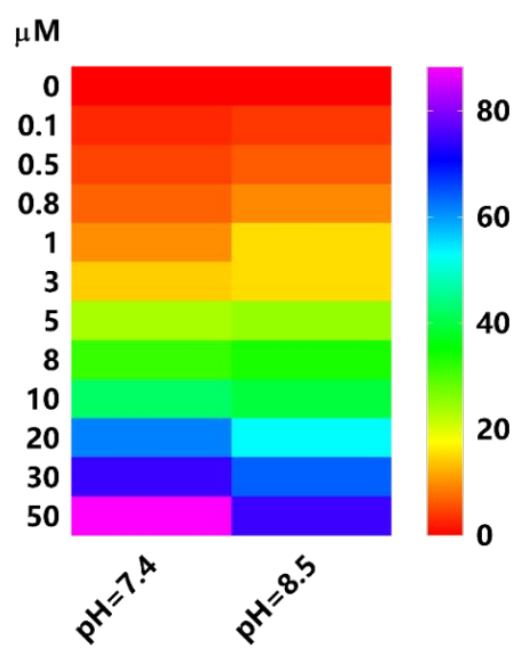

Figure S19. Heat map derived from the TRF response patterns of $\mathrm{BSA} / \mathrm{Tb}^{3+}$ sensors against $\mathrm{Fe}^{3+}$.

a

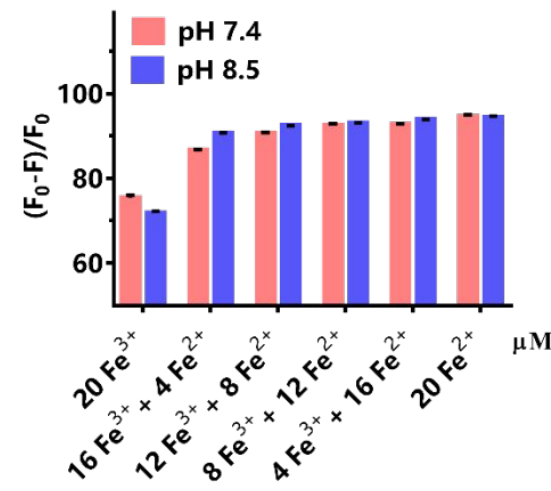

b

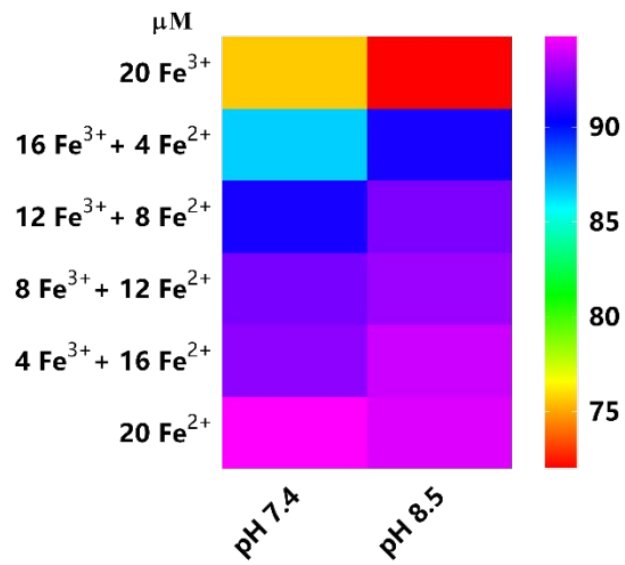

Figure S20. (a) TRF response patterns of BSA/ $\mathrm{Tb}^{3+}$ sensors against the mixture of $\mathrm{Fe}^{2+}$ and $\mathrm{Fe}^{3+}$. (b) Heat map derived from the TRF response patterns of BSA $/ \mathrm{Tb}^{3+}$ sensors against the mixture of $\mathrm{Fe}^{2+}$ and $\mathrm{Fe}^{3+}$.

a

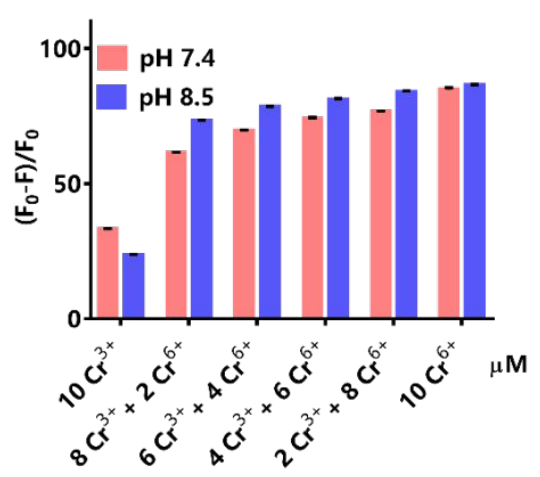

b

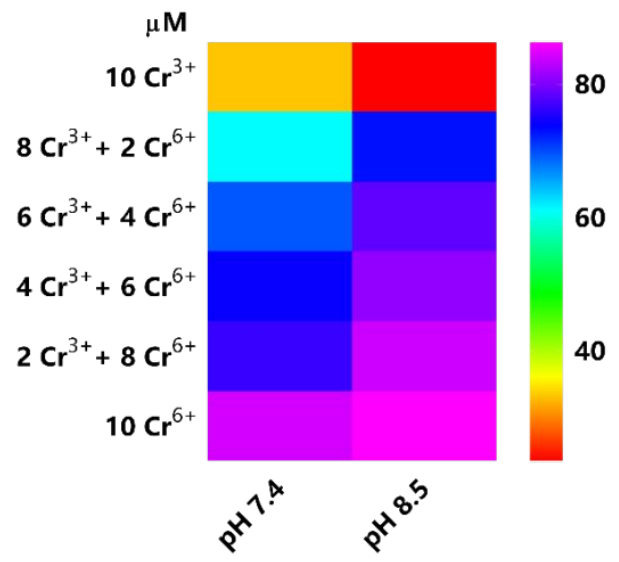

Figure S21. (a) TRF response patterns of BSA/ $\mathrm{Tb}^{3+}$ sensors against the mixture of $\mathrm{Cr}^{3+}$ and $\mathrm{Cr}^{6+}$. (b) Heat map derived from the TRF response patterns of $\mathrm{BSA} / \mathrm{Tb}^{3+}$ sensors against the mixture of $\mathrm{Cr}^{3+}$ and $\mathrm{Cr}^{6+}$. 


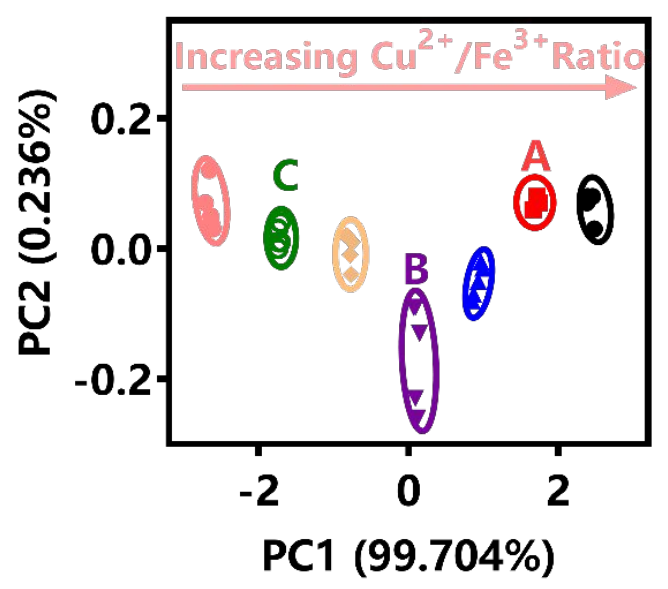

\begin{tabular}{|c|c|c|c|c|c|c|}
\hline \multicolumn{4}{|c|}{$\mathrm{Cu}^{2+} / \boldsymbol{\mu M}$} \\
Entry & Actual & ICP-AES & Tb/BSA & Actual & ICP-AES & Tb/BSA \\
\hline A & 8 & 8.12 & $6-10$ & 2 & 2.17 & $0-4$ \\
\hline B & 5 & 5.28 & $4-6$ & 5 & 5.15 & $4-6$ \\
\hline C & 2 & 1.98 & $0-4$ & 8 & 8.16 & $6-10$ \\
\hline
\end{tabular}

Figure S22. PCA plots for the TRF patterns of BSA/Tb ${ }^{3+}$ sensors toward the mixtures of $\mathrm{Cu}^{2+} / \mathrm{Fe}^{3+}$ in artificial saliva. Table shows the performances of $\mathrm{BSA} / \mathrm{Tb}^{3+}$ sensors compared with ICP-AES.

Table S1. Detection of $\mathrm{Fe}^{3+}$ in Sweat using BSA/ $\mathrm{Tb}^{3+}$ sensor array.

\begin{tabular}{cccccc}
\hline Entry & $\begin{array}{c}\text { Actual } \\
(\mu \mathrm{M})\end{array}$ & $\begin{array}{c}\text { ICP-AES } \\
(\mu \mathrm{M})\end{array}$ & $\begin{array}{c}\text { Tb/BSA } \\
\text { Sweat }\end{array}$ & $\begin{array}{c}\text { Recovery } \\
(\%)\end{array}$ & RSD (\%) \\
\hline & 10 & 10.46 & 10.64 & 106.4 & 2.56 \\
& 15 & 15.31 & 14.76 & 98.4 & 1.78 \\
& 20 & 21.37 & 19.73 & 98.65 & 3.82 \\
\hline
\end{tabular}


Table S2. Comparison about sensitivity between this work and other fluorescent sensors for detection of $\mathrm{Cu}^{2+}$.

\begin{tabular}{cccccc}
\hline $\begin{array}{c}\text { Fluorescent } \\
\text { sensors }\end{array}$ & $\begin{array}{c}\text { Linear } \\
\text { detection range }\end{array}$ & $\begin{array}{c}\text { Limit of } \\
\text { Detection }\end{array}$ & $\begin{array}{c}\text { Species of } \\
\text { metal ions }\end{array}$ & Applications & Ref. \\
\hline $\begin{array}{c}\text { PEI-based } \\
\text { polymer } \\
\text { nanoparticles }\end{array}$ & $0-8 \mu \mathrm{M}$ & $62 \mathrm{nM}$ & 1 & River water & 1 \\
hPEI-AgNCs & $0.01-7.7 \mu \mathrm{M}$ & $10 \mathrm{nM}$ & 1 & River water & 2 \\
$\begin{array}{c}\text { Au-GSH } \\
\text { nanoclusters }\end{array}$ & $0.3-16 \mu \mathrm{M}$ & $109 \mathrm{nM}$ & 2 & Drinking water & 3 \\
$\begin{array}{c}\text { Tb/BSA sensor } \\
\text { array }\end{array}$ & $0.1-50 \mu \mathrm{M}$ & $8.06 \mathrm{nM}$ & 17 & Biofluids & This work \\
\hline
\end{tabular}

Table S3. Comparison about sensitivity between this work and other fluorescent sensors for detection of $\mathrm{Fe}^{3+}$.

\begin{tabular}{cccccc}
\hline $\begin{array}{c}\text { Fluorescent } \\
\text { sensors }\end{array}$ & $\begin{array}{c}\text { Linear } \\
\text { detection range }\end{array}$ & $\begin{array}{c}\text { Limit of } \\
\text { Detection }\end{array}$ & $\begin{array}{c}\text { Species of } \\
\text { metal ions }\end{array}$ & Applications & Ref. \\
\hline La-CNNS & $0.1-20 \mu \mathrm{M}$ & $23.2 \mathrm{nM}$ & 1 & Natural water & 4 \\
S-doped C-dots & $1-500 \mu \mathrm{M}$ & $100 \mathrm{nM}$ & 1 & Not mentioned & 5 \\
$\begin{array}{c}\text { pyrazolo[3,4- } \\
\text { h]quinoline-3- } \\
\text { carbonitriles }\end{array}$ & $0-500 \mu \mathrm{M}$ & $860 \mathrm{nM}$ & 1 & $\begin{array}{c}\text { Drinking, river } \\
\text { water }\end{array}$ & 6 \\
$\begin{array}{c}\text { Tb/BSA sensor } \\
\text { array }\end{array}$ & $0.5-50 \mu \mathrm{M}$ & $6.27 \mathrm{nM}$ & 17 & Biofluids & This work \\
\hline
\end{tabular}

\section{References:}

(1) Liu, S. G.; Li, N.; Fan, Y. Z. Intrinsically Fluorescent Polymer Nanoparticles for Sensing $\mathrm{Cu}^{2+}$ in Aqueous Media and Constructing an IMPLICATION Logic Gate. Sens. Actuators B: Chem. 2017, 243, 634-641.

(2) Yuan, Z.; Cai, N.; Du, Y.; He, Y.; Yeung, E. S. Sensitive and Selective Detection of Copper Ions with Highly Stable Polyethyleneimine-protected Silver Nanoclusters. Anal. Chem. 2014, 86, 419- 426.

(3) Jia, Y.; Sun, T.; Jiang, Y. Green, Fast, and Large-scale Synthesis of Highly Fluorescent Au Nanoclusters for $\mathrm{Cu}^{2+} \mathrm{Detection}$ 
and Temperature Sensing. Analyst. 2018, 143, 5145-5150.

(4) Zhang, H. Q.; Huang, Y. H.; Lin, X. H. Lanthanum Loaded Graphitic Carbon Nitride Nanosheets for Highly Sensitive and Selective Fluorescent Detection of Iron Ions. Sens. Actuators B: Chem. 2018, 255, 2218-2222.

(5) Quan, X.; Peng, P.; Zhao, J. G.; Dong, C. B.; Cao, C.; Zhou, H. J. Preparation of Highly Photoluminescent Sulfur-doped Carbon Dots for Fe (III) Detection. J. Mater. Chem. A. 2015, 3, 542-546.

(6) Adaikalam, S.; Somi, S. R.; Rakkappan, V. P.; Raju, R.K. Four-Component Domino Synthesis of Pyrazolo[3,4-h]quinoline3-carbonitriles: “Turn-Off” Fluorescent Chemosensor for Fe ${ }^{3+}$ Ions. J.Org. Chem. 2018, 83, 14084-14090. 